DOI https://doi.org/10.18551/rjoas.2018-03.23

\title{
FACTORS INFLUENCING PRODUCTION DECISIONS AND HOUSEHOLD CONSUMPTION OF SUGAR CANE (SACCHARUM OFFICINARUM) FARMERS IN INDONESIA
}

\author{
Rizkiyah Noor* \\ Post-graduate Program of Agriculture, Faculty of Agriculture, University of Brawijaya \& \\ Faculty of Agriculture, Universty of Antakusuma Pangkalan Bun, Indonesia
}

Koestiono Djoko, Setiawan Budi, Hanani Nuhfil

Departement of Agribusiness, Faculty of Agriculture, University of Brawijaya

*E-mail: noorrizkiyah@yahoo.com

\begin{abstract}
This research aims to determine factors influencing economic decision- making of sugarcane farmers' household in terms of production, labor allocation and consumption. This research was conducted in Malang, East Java, Indonesia. The number of respondents, based on the ratoons rate, was 172 sugarcane households. Parameter estimation was conducted using two-stage least square method. Parameter estimation showed that non family labor allocation of sugarcane farming was influenced by sugarcane farm, the use of ZA fertilizer, wage rate of nonfamily woman labor of sugarcane farming, and ratoons frequency. Family labor allocation of sugarcane farming was actually influenced by sugarcane farm, a family labor of sugarcane farming, total family members, and rations frequency.
\end{abstract}

\section{KEY WORDS}

Household economics, production, sugarcane, labor allocation.

Sugarcane is a sugar-producing plant that has seasonal growth because influenced by climate. Sugar production trend in 1993/94 in Indonesia significantly decreased due to the impact of drought (T.M.Hess et al., 2016). As a sugar-producing plant which has not been replaced, sugarcane is an important crop globally. While the effect of sugar consumption is highly debated Ruxton et al. (as cited in T.M.Hess et al., 2016). In 2013, Brazil and India globally account for $39 \%$ and $18 \%$ of sugarcane production (FAOSTAT, 2015). The largest sugarcane producers in the world are Brazil, Thailand, and Australia. While Indonesia is a producer-consumer country.

This is indicated by the imported value of plantation commodities that packed the domestic market of $32.49 \%$ with a growing volume of $26.50 \%$. Most imported plantation commodity is refined sugar crystal (Director General of Plantation, 2015). According to the Ministry of Industry (2016), the increase of sugar import was caused by the sugar needs for household consumption which reached 2.7 million tons and 3.5 million tons of refined sugar for food and beverage industry so that the total demand for sugar in 2017 reached up to 6.2 million tons, while production in 2016 was only 2.2 million tons.

Production center of sugarcane in Indonesia spread in several provinces and the largest sugarcane plantation development was done by society under the condition of not using technology yet that can optimize production input. According to the data from the Ministry of Agriculture (2016), the province with the largest harvest area and sugarcane producer during the $2012-2016$ period was East Java which was recorded to have an area of land by 209.33 ha or $45.06 \%$ of a total land area of sugarcane plantations in Indonesia. Moreover, the average production was 1.28 million tons per year, so this production contributes $49.14 \%$ of annual Indonesia's sugar cane production. In addition, Malang Regency, with most of ratoon cane development, was listed as an area which has plantation land up to 44, $057 \mathrm{Ha}$. 
This condition makes sugarcane plantations the main livelihood of the farmers household. However, in 2014, with plantation area of 3, 786 ha, its productivity reached 160 tons/ha, lower than in 2013 with plantation area by 2, 705 hectares and the productivity by 180 tons/ha (Agricultural Extension Center 2015). As a result, the accretion of plantation area did not affect the increase of sugarcane production, according to Fitriani (2013) the intensity of activity in sugarcane farm was also determined by the availability of capital, production input, cultivation technology and certainty of sugarcane selling price at the factory level, in addition was also determined by external factors such as wages, input price, output price and farmers' awareness of the importance of the cultivated commodities. According to Khumbakar (2002), agricultural production was highly dependent on the managerial ability of farmers in farming. Farmers household acts as a producer and consumer, according to Becker (1965) when acting as producer, a farmer maximizes profits while acting as a consumer, a farmer maximizes the satisfaction of goods consumed and the allocation of spare time. Total household time was allocated to combine the production of goods and leisure, for agriculture or off-farm (Barnum and Square 1979) then Ellis (1988) states that households have the freedom to work in the household (in the family) and to hire labor from outside the household with the applicable wage rates.

So that fluctuating sugarcane productivity condition makes sugarcane farmers have a tendency of simultaneous-decision making pattern between production and consumption activity. Thus the economic decision making of the household of sugarcane farmers cannot be analyzed partially. As the previous research conducted by Ratna (2007) who analyzed the household economics of crop farmers. Hanani and Yonekure (2009); Fitriani (2013); Leki et.al (2016); Makki (2014) analyze household economics decision making to build household economics model.

Based on the description above, this research is important to be done to identify factors influencing production, labor allocation and consumption as household economics decision making of a sugarcane farmer.

\section{METHODS OF RESEARCH}

Research Location. This research was conducted purposively in Malang Regency of East Java Indonesia. This location was chosen because Malang has the largest sugarcane plantation and there are 2 sugar factories there. Through the non-proportioned stratified random sampling, ratoons level was divided into a level I for 3-4 ratoons, level II for 5-10 ratoons and level III > 10 ratoons. Total ratoons selected were 172 sugarcane farmers

Data Analysis Method. The analysis used to fulfill the research objectives was an estimation of a production function, labor allocation and sugarcane farmers consumption using simultaneous equation (2 SLS). By the help of software (SAS/ETS) version 9.1, it was then specifically divided into four blocks of structural and identity equations, namely (a) labor allocation block comprised the use of family and non-family labor for sugarcane and nonsugarcane farming (b) production and production facility block meant production of sugarcane, non-sugarcane, ZA fertilizer and NPK fertilizer (c) income block consisted of sugarcane farming income, non-sugarcane farming income, total income of sugarcane farmers household and surplus of household income of sugarcane farmers (d) block of households spending of sugarcane farmers, namely the food consumption expenditure and non-food consumption expenditure. The estimation of the model as a whole was part of the economic decision-making model (Bagi and Singh, 1974). In this study, household economics decision making of sugarcane farmers was classified into labor allocation, production, and production facility, income and household expenditure of sugarcane farmers in form of equation as follows:

a) Production Facility equation and Labor Allocation:

NFLSF $=a_{0}+a_{1} S F A+a_{2} N F M+a_{3} U Z A F+a_{4}$ WNFLSFw $+a_{5}$ dummy $F R+U_{1}$

$\mathrm{FLSF}=\mathrm{b}_{0}+\mathrm{b}_{1} \mathrm{SFA}+\mathrm{b}_{2} \mathrm{FLnSF}+\mathrm{b}_{3} \mathrm{NFM}+\mathrm{b}_{4}$ dummy $\mathrm{FR}+\mathrm{U}_{2}$

TLSF $=$ NFLSF + FLSF

$\mathrm{NFLnSF}=\mathrm{C}_{0}+\mathrm{C}_{1} \mathrm{TSFI}+\mathrm{C}_{2} \mathrm{TLnSF}+\mathrm{C}_{3} \mathrm{FE}+\mathrm{U}_{3}$ 


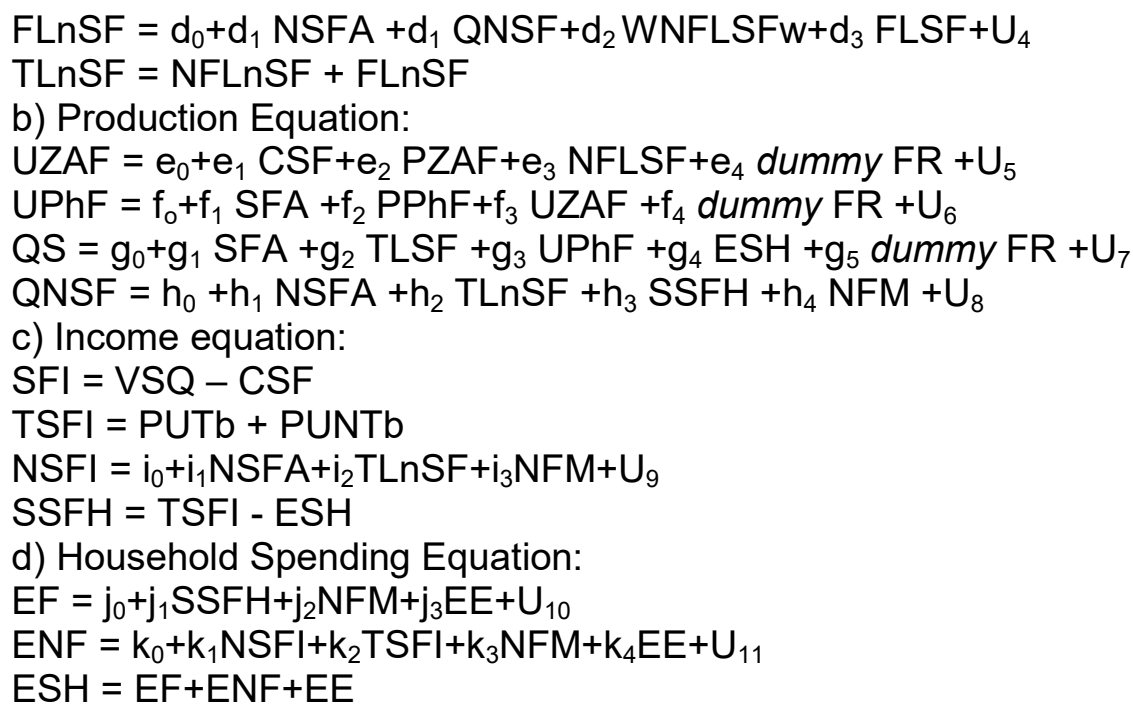

Model identification. According to Koutsoyiannis (1987), in the event of building a model, the process of identifying structural models should take into account (1). The total number of variables in the model (2) the number of variables in each equation (3) the number of predetermined variables in the model and (4) the number of predetermined variables in each equation. So the requirement of identification conditions was achieved if $(K-M) \geq(G-1)$. The equation model of this research consisted of 11 structural equations and 6 identity equations. With the total variables $27(\mathrm{~K}=27)$ and $\mathrm{M}=6, \mathrm{G}=17$ then the result of equation model was over-identified, because (K-M) was greater than (G-1). Variable notation description of equation model was shown in table 8.

\section{RESULTS AND DISCUSSION}

Household economics-decision making of sugarcane farmers. Most of sugarcane farming activities in the research area was people's sugarcane of dry land farming. Cultivation of dry land allows ratoons system application. Ratoons was a sugarcane crop that was previously cut, then the stubble was cut right or lower than the surface of the bund then managed to produce (Koswara in Angga Naruputro, 2009). In general, ratoon cane has lower productivity than the planting cane. As a result, the decision of ratoons was not separated from the households decision-making of sugarcane farmers, as well as its relation to the replanting that requires high farming costs

Household income source for sugarcane farmers. Sources of income were comprised income from sugarcane and non-sugarcane farming, it was in line with Rochaeni and Lakollo EM's (2005) research. Sugarcane farming income contributes greatly because sugarcane was the main livelihood. In addition, the research location was historical area and expansion area shown by the existence of two sugar factoriesm, while income from non-sugarcane farming system comes from food crop and horticultural crops. The average income of sugarcane farmers household can be seen on.

Table 1 - Source of income and average household income of ratoon cane farmers in Malang District, Indonesia, 2016

\begin{tabular}{|c|c|c|c|}
\hline No. & Source of income & Value (Rp/Year) & Percentage (\%) \\
\hline 1 & Sugarcane Farming & 36.517 .830 & 87,56 \\
\hline 2 & Non Sugarcane Farming & 5.186 .196 & 12,44 \\
\hline \multicolumn{2}{|c|}{ Total } & 41.704 .026 & 100 \\
\hline
\end{tabular}

Source: Primary Data (2017), processed.

Household labor allocation of sugarcane farmers. Sugarcane farmers household devotes their labor for on-farm activity, that was sugarcane and non-sugarcane farming. The allocation of non-sugarcane farming was the real total time of family labor allocated to 
farming activities excluding sugar cane Fadilla et.al (2017) such as rice, corn, chili, and papaya. The table shows that the household labor allocates the time in the sugarcane farming activity, considering the farming as the main livelihood. Allocation of the household labor of sugarcane farmers was on.

Table 2 - Average of household labor allocation of sugarcane farmers in Malang District, Indonesia, 2016

\begin{tabular}{|c|c|c|c|}
\hline No. & Avarage of household labor of Sugarcane farmers & Value (HOK) & Percentage (\%) \\
\hline 1 & Sugarcane Farming & 269,39 & 78,28 \\
\hline 2 & Non Sugarcane Farming & 74,75 & 21,72 \\
\hline \multicolumn{2}{|c|}{ Total } & 343,14 & 100 \\
\hline
\end{tabular}

Source: Primary Data (2017), processed.

Household spending allocation of sugarcane farmers. Household income of sugarcane farmers was allocated to household spending, i.e. food, non-food and energy consumption. Table 3 indicates that food consumption expenditure has the greatest percentage, in line with Sekhampu et.al (2013) stating that lower middle-income household spending was dominated by basic needs. Non-food consumption includes the purchase of clothing, recreation, communication, social participation, and energy.

Table 3 - Average expenditure on food and non-food of sugarcane farmers in Malang District, Indonesia, 2016

\begin{tabular}{|c|c|c|c|}
\hline No. & Expenditure of household of Sugarcane farmers & Value (Rp/Year) & Percentage (\%) \\
\hline 1. & Expenditure on food & 9.165 .837 & 85,34 \\
\hline 2. & Expenditure non food & 1.574 .500 & 14,66 \\
\hline \multicolumn{2}{|c|}{ Total } & 10.740 .337 & 100 \\
\hline
\end{tabular}

Source: Primary Data (2017), processed.

Estimation of factor parameters that influence production and consumption decisionmaking of sugarcane household. Estimation results indicate that the model has met the criteria of economics, statistics, and econometrics (Koutsoyiannis, 1977). The value of the coefficient of determination $\left(R^{2}\right) 50 \%$ has a high value, the higher $\left(R^{2}\right)$, the better the structural equation, because the diversity of endogenous variables can be explained by exogenous variables. The result of statistical test $F$ showed that all structural equations have a probability $\mathrm{F}$ under the real level of $10 \%$. Thus the exogenous variables were together able to explain the endogenous variables. The estimation of sugarcane farming parameter and equation model was as follows;

Blocks of labor allocation for sugarcane farming. The formation of the labor in sugarcane farming consisted of family and non-family labor. The analysis result of family labor allocation of sugarcane farming was positively influenced by variables of sugarcane farm, the use of fertilizer ZA, wages of non-family woman labor of sugarcane farming and ratoons frequence dummy and significant at the level of real 10\%, except family member variable of sugarcane farmers family. Sugarcane farming activities are labor-intensive so that the addition of family members did not significantly affect the use of the hired workers or nonfamily labor. In line with the research done by Chang et.al (2011) that household demands non family labor will not decrease unless the family labor is complimentary. The use of the family labor of sugarcane farmers household was significantly and positively influenced by the variable of sugarcane farm, the number of family members and the dummy of ratoons frequency, while the family labor of sugarcane farms has a significant and negative influence. Therefore, the addition of the use of family labor in the non-sugarcane farm of 1 HOK (manday) will reduce the use of family labor in sugar cane farm. Food crops and horticulture activity required the sugarcane farmers household to be intensive because having a high production risk trend.

Non-sugarcane labor allocation. Labor allocation of this activity was divided into family and non-family labor. Factors that influence the use of the non-family labor of sugarcane 
farm were the total non-sugarcane labor with a positive and significant response. When there was $1 \%$ increase in total labor allocation non-sugarcane so non-family and non-sugarcane labor increased 0, 99 HOK (man-day). Non-family labor of non-sugarcane farming were substituted to the family labor allocation. While the total income variable of sugarcane farming household and food consumption expenditure were negative and insignificant to nonsugar cane and non-family labor allocation. Family labor allocation of non-sugarcane farming, non-sugarcane farm, and non-sugarcane production variable have a positive and significant influence on the real level of $10 \%$. In addition to growing sugarcane, farmers also cultivate food crops and horticulture as a source of non-sugarcane income. While the nonfamily woman labor wage of sugarcane farming and family labor of sugarcane farming was not significant to the family labor allocation in the non-cane farming system. The estimation result of labor allocation of sugarcane farmers household was shown at table 4.

Table 4 - The results of the estimation parameters of labor allocation of sugarcane and non sugarcane farming, Malang Regency, Indonesia 2016

\begin{tabular}{|c|c|c|c|c|}
\hline No & Variable & $\begin{array}{l}\text { Estimation } \\
\text { Parameter }\end{array}$ & Prob > $|t|$ & Explanatory variables \\
\hline \multirow[t]{7}{*}{1.} & \multicolumn{4}{|c|}{ Non family labor of sugarcane farming (NFLSF) } \\
\hline & Intercept & $-80,9974$ & 0.0053 & \\
\hline & SFA & 286,0805 & $<.0001$ & Sugarcane farm area \\
\hline & NFM & 1,165513 & 0.8526 & Number of family member \\
\hline & UZAF & 0,123659 & $<.0001$ & Use of ZA fertilizer \\
\hline & WNFLSFW & 0,000020 & 0.0002 & Wages of woman non-family labor of sugarcane farming \\
\hline & $\mathrm{FR}$ & 74,03979 & 0.0008 & dummy ratoon frequency \\
\hline \multirow[t]{6}{*}{2.} & \multicolumn{4}{|c|}{ Family labor of sugarcane farming (FLSF) } \\
\hline & Intercept & $-14,8794$ & 0.0001 & \\
\hline & SFA & 51,07299 & $<.0001$ & Sugarcane farming area \\
\hline & FLnSF & $-0,09640$ & 0.0237 & Family labor of non-sugarcane farming \\
\hline & NFM & 3, 952290 & $<.0001$ & Number of family member \\
\hline & FR & 14,12867 & $<.0001$ & Dummy ratoon frequency \\
\hline \multirow[t]{5}{*}{3.} & \multicolumn{4}{|c|}{ Non family labor of non-sugarcane farming (NFLnSF) } \\
\hline & Intercept & $-11,1801$ & 0.2559 & \\
\hline & TSFI & $-1,47 \mathrm{E}-07$ & 0.1749 & Total of household sugarcane farming income \\
\hline & TNFLnSF & 0,996489 & $<.0001$ & Total Non family labor of non-sugarcane farming \\
\hline & ENF & $-1,15 \mathrm{E}-06$ & 0,2085 & Non food expenditure \\
\hline \multirow[t]{6}{*}{4.} & \multicolumn{4}{|c|}{ Family labor of non-sugarcane farming (FLnSF) } \\
\hline & Intercept & 4,593459 & 0,0890 & \\
\hline & NSFA & 80,81361 & $<.0001$ & Non sugarcane farming area \\
\hline & QNSF & 0,003206 & 0,0068 & Non-sugarcane production \\
\hline & WNFLSFW & $-3,96 \mathrm{E}-07$ & 0.6702 & Wages of non-family woman labor of sugarcane farming \\
\hline & FLSF & $-0,03813$ & 0,3885 & Family labor of sugarcane farming \\
\hline
\end{tabular}

Note: significant at $10 \%$.

Block production and production facilities of sugarcane farming. The equation of the amount of fertilizer ZA use was influenced by sugarcane farming cost variable, fertilizer ZA price, non -family labor of sugarcane farming and a dummy of rootans frequency. All exogenous variables have a positive effect on the amount of fertilizer ZA use except ratoons frequence dummy which has a negative and significant influence. The cost of sugarcane farming was the cost incurred by sugarcane farmers household in the cultivation of sugarcane, the high cost of farming was shown by the increasing number of total inputs. The price of fertilizer ZA has an effect on the amount of fertilizer ZA use, in sugarcane farming, fertilizer ZA was one of useful single fertilizer to result in optimum production so that in its use the farmer will not decrease the amount as accordingly. While non family labor variable has a positive influence on the use of fertilizer ZA but not significant at $\alpha=10 \%$, sugarcane farming labor consists of family and nonfamily labor substitution whose characteristic was a substitution. While the dummy variable of ratoons frequency has a negative and significant coefficient sign. Theoretically, the higher the ratoon frequency, the higher the application of fertilizer ZA, but empirically sugarcane farmers applied ZA fertilizer in accordance with the dose recommended by PG of $6-7 \mathrm{ku} / \mathrm{ha}$. The research area was a cultivation of dry land 
cane with ratoons cultivation. In line with the research results of Angga Naruputro (2009) the addition of fertilizer ZA dose for ratoons cane on dry land will have a little effect even not have an influence on the addition of sugarcane weight.

For the use of phonska fertilizer based on parameter estimation results, the influential variables were sugarcane farm, Phonska fertilizer price, ZA fertilizer application and actual ratoons frequency dummy. A very positive and significant variable was the use of ZA fertilizer. ZA and Phonska fertilizers were complementary like the research result by Fadilla (2017) that in sugarcane farming. Phonska and ZA fertilizers were complementary in a certain proportion to obtain optimal production, while ratoons frequency dummy has a negative but not significant influence.

Estimation result of parameters for sugarcane production was influenced jointly by the variable of sugarcane farming area, a total labor of sugarcane farming, Phonska fertilizer use, the household expenditure of sugarcane farmers and ratoons frequency dummy. All variables were positive and in accordance with the expectations except the use of Phonska fertilizer was negative but significant, because it was complimentary with ZA fertilizer then the application should be combined with ZA fertilizer, in addition, the dosage of Phonska fertilizer was in accordance with the recommended, that was $4 \mathrm{ku} / \mathrm{ha}$. While the dummy frequency of ratoons was negative and not significant. Partially, the most influential variable affecting sugarcane production were sugarcane farming area. Like the research conducted by M.Dina et.al (2011) that group of sugarcane farmers with the narrow land area was not economically efficient compared to middle and big farmer group.

For non-sugarcane production, the positive variables included non-sugarcane farming area, total non-sugarcane labor, a surplus of sugarcane farmers household and the number of household members of sugarcane farmer household. However, a not-significant variable was the number of family members of sugarcane farming. For the estimation result of production and production of sugarcane was found at table 5 .

Table 5 - The result of estimation of production block and production facility of sugarcane farming, Malang Regency, Indonesia, 2016

\begin{tabular}{|c|c|c|c|c|}
\hline No & Variable & $\begin{array}{l}\text { Estimation } \\
\text { Parameter }\end{array}$ & Prob $>|t|$ & Explanatory variables \\
\hline \multirow[t]{6}{*}{1.} & \multicolumn{4}{|c|}{ Use of ZA Fertilizer (UZAF) } \\
\hline & Intercept & $-246,429$ & 0.2690 & \\
\hline & CSF & 0.000024 & 0.0005 & Cost of sugarcane farming \\
\hline & PZAF & 0,260250 & 0.0686 & Price of ZA fertilizer \\
\hline & NFLSF & 0,204737 & 0.7028 & Non family labor of sugarcane farming \\
\hline & FR & $-238,364$ & 0.0121 & dummy ratoon frequency \\
\hline \multirow[t]{6}{*}{2.} & \multicolumn{4}{|c|}{ Use of Phonska Sugarcane Farming (UPhF) } \\
\hline & Intercept & -148.576 & 0.7871 & \\
\hline & SFA & 35.35719 & 0.7141 & Sugarcane farming area \\
\hline & PPhF & 0,155819 & 0.5417 & Price of Phonska fertilizer \\
\hline & UZAF & 0,322499 & $<.0001$ & Use of ZA fertilizer \\
\hline & $\mathrm{FR}$ & $-81,7205$ & 0.3152 & Dummy ratoon frequency \\
\hline \multirow[t]{7}{*}{3.} & \multicolumn{4}{|c|}{ Sugarcane production (QS) } \\
\hline & Intercept & 6,199911 & 0.3192 & \\
\hline & SFA & 82,94920 & $<.0001$ & Sugarcane farming area \\
\hline & TLSF & 0,014651 & 0.4488 & Total labor of sugarcane farming \\
\hline & UPhF & $-0,02287$ & 0.0159 & Use of Phonska fertilizer \\
\hline & ESH & 1, 156E-06 & 0.0072 & Sugarcane household expenditure \\
\hline & FR & $-0,74496$ & 0.8479 & Dummy ratoon frequency \\
\hline \multirow[t]{6}{*}{4.} & \multicolumn{4}{|c|}{ Non sugarcane production (QNSF) } \\
\hline & Intercept & $-108,010$ & 0.8555 & \\
\hline & NSFA & 3394,166 & $<.0001$ & Non sugarcane farming area \\
\hline & TLnSF & 0,183588 & 0.0747 & Total labor of non sugarcane farming \\
\hline & SSFH & 0,000011 & 0.0494 & Surplus of sugarcane farmers households \\
\hline & NFM & 61,25451 & 0.5973 & Number of family member \\
\hline
\end{tabular}

Note: significant at $10 \%$. 
Block of household income of cane farming. The equation for farming income was the identity equation which was the result of sugar cane production value with the cost of sugarcane farming. The equation of sugarcane production value comes from sugar cane production (QS) multiplied by the price of sugarcane. Thus, sugarcane farming income resulted from the reduction of sugar production value and sugarcane farming cost. Total household income of sugarcane farmers was the sum of sugarcane farming income and nonsugarcane farming income (NSFI). Similarly for the Surplus of Sugarcane Farmers Households (SSFH) which was the difference between the total income of sugarcane farm households with the expenditure of sugarcane households. The structural equation of nonsugarcane farming income was influenced by non-sugarcane farming area, non-sugarcane farm labor, the number of family member of a sugarcane farmer. The result of parameter estimation, a non-sugarcane farming land variable has a positive and significant influence on non-sugarcane farming income, while the total labor of non-sugarcane was positive but not significant and the number of family member of sugarcane farmers a negative and unreal effect. The estimation of household income parameters of sugarcane farmer was shown on table 6.

Block of household expenditure of sugarcane farmers. Household expenditure of sugarcane farmers consists of food, non-food and energy expenditure. The result of estimation of parameters of food expenditure was influenced by a surplus of farmers household, the number of family member of sugarcane farmer and household energy expenditure of sugarcane farmer. All of these variables were positive and significant, when the surplus of sugarcane farmer household increased, food expenditure also increased. In accordance with the research result of Fitriani (2013) that the results of estimation of income variables were positive and significant, the sign of parameters of income variables was economically in accordance with the positive theory influencing food consumption. Furthermore, the addition of the number of family members will increase the food expenditure, so in accordance with the condition that a large number of family members will affect household food consumption. When household energy expenditure of sugar cane farmers increased by $1 \%$, it would increase food expenditure by $2.52 \%$.

Tabel 6 - Estimation results of non-sugarcane income, food expenditure, non-food and household energy of sugarcane farmers in Malang Regency Indonesia, 2016

\begin{tabular}{|c|c|c|c|c|}
\hline No & Variable & $\begin{array}{l}\text { Estimation } \\
\text { Parameter }\end{array}$ & Prob $>|t|$ & Explanatory variables \\
\hline \multirow[t]{5}{*}{1.} & \multicolumn{4}{|c|}{ Non sugarcane farm income (NSFI) } \\
\hline & Intercept & 3167512 & 0.0185 & \\
\hline & NSFA & 12416297 & $<.0001$ & Non sugarcane farming area \\
\hline & TLnSF & 41,59505 & 0.8589 & Total labor of non sugarcane farming \\
\hline & NFM & -352277 & 0,2191 & Number of family member \\
\hline \multirow[t]{5}{*}{2.} & \multicolumn{4}{|c|}{ Food Expenditure (EF) } \\
\hline & Intercept & 2709749 & 0.0098 & \\
\hline & SSFH & 0,020944 & 0.0090 & Surplus of Sugarcane Farmers Households \\
\hline & NFM & 751193.7 & $<.0001$ & Number of family member \\
\hline & EE & 2.526282 & $<.0001$ & Household energy expenditure of sugarcane farmer \\
\hline \multirow[t]{5}{*}{3.} & \multicolumn{4}{|c|}{ Non food expenditure (ENF) } \\
\hline & Intersep & 475780.0 & 0.0002 & \\
\hline & TISF & 0.002707 & 0.0035 & Total income of household sugarcane farming \\
\hline & NFM & -29807.0 & 0.1493 & Number of family member \\
\hline & EE & 0,072778 & 0.2171 & Household energy expenditure of sugarcane farmer \\
\hline
\end{tabular}

Note: significant at $10 \%$.

Non-food expenditure equation, income variable of non-sugarcane farming and total household income of farmers have a positive and significant influence. Furthermore, for a partial influence of an independent variable on a non-free variable, that was non-food expenditure indicated that energy expenditure has a positive but not significant effect. While the number of family members variable was negative and not significant. For statistical test values $R^{2,} F$, and F-statistics can be seen on table 7 . 
Table 7 - Indicator value R2-Statistic, F-Value, Probability F from Structural Equation

\begin{tabular}{lllcl}
\hline No. & Dependent Variabel & R2 & F-value & Pro-F \\
\hline 1. & NFLSF & 0.87010 & 222.38 & $<.0001$ \\
2. & FLSF & 0.85834 & 252.98 & $<.0001$ \\
3. & NFLnSF & 0.99944 & 1000594 & $<.0001$ \\
4. & FLnSF & 0.59097 & 60.32 & $<.0001$ \\
5. & UZAF & 0.68138 & 89.28 & $<.0001$ \\
6. & UPHF & 0.32066 & 19.71 & $<.0001$ \\
7. & QS & 0.89225 & 274.91 & $<.0001$ \\
8. & QNSF & 0.22392 & 12.05 & $<.0001$ \\
9. & NSFI & 0.32009 & 26.36 & $<.0001$ \\
10. & EF & 0.20038 & 14.03 & $<.0001$ \\
11. & ENF & 0.06718 & 4.03 & 0.0084 \\
\hline
\end{tabular}

Table 8 - Variable Name from Structural Equation

\begin{tabular}{|c|c|c|}
\hline 1. NFLSF & $=$ & Non-family labor of sugarcane farming \\
\hline 2. FLSF & $=$ & Family labor of sugarcane farming \\
\hline 3. TLSF & $=$ & Total labor of Sugarcane Farming \\
\hline 4. NFLnSF & $=$ & Non family labor of non-sugarcane farming \\
\hline 5. FLnSF & $=$ & Family labor of non sugarcane farming \\
\hline 6. TLnSF & $=$ & Total labor of non sugarcane farming \\
\hline 7. UZAF & $=$ & The Use of ZA Fertilizer \\
\hline 8. UPhF & $=$ & The Use of Phonska Fertilizer \\
\hline 9. QS & $=$ & Sugarcane Production \\
\hline 10. QNSF & $=$ & Non-sugarcane Production \\
\hline 11. SFI & $=$ & Sugarcane farm income \\
\hline 12. TSFI & $=$ & Total income of household sugarcane farmer \\
\hline 13. NSFI & $=$ & Non sugarcane farm income \\
\hline 14. SSFH & $=$ & Surplus of sugarcane farmers household \\
\hline 15. EF & $=$ & Food Expenditure \\
\hline 16. ENF & $=$ & Non Food Expenditure \\
\hline 17. ESH & $=$ & Sugarcane Household Expenditure \\
\hline 18. SFA & $=$ & Sugarcane farming area \\
\hline 19. NFM & $=$ & Number of Family Member \\
\hline 20. WNFLSF ${ }_{W}$ & $=$ & Wage of woman non family labor of sugarcane farming \\
\hline 21. NSFA & $=$ & Non sugarcane Farming area \\
\hline 22. CSF & $=$ & Cost of Sugarcane Farming \\
\hline 23. PZAF & $=$ & Prices of ZA fertilizer \\
\hline 24. PPhF & $=$ & Prices of Phonska fertilizer \\
\hline 25. VSQ & $=$ & Value of sugarcane production \\
\hline 26. EE & $=$ & Energy expenditure \\
\hline 27. FR & $=$ & dummy ratoon frequency \\
\hline
\end{tabular}

\section{CONCLUSION AND SUGGESTIONS}

Based on the result of the discussion, economic-decision making of sugarcane farmers household in the allocation of non-family labor allocation of sugar cane farming was influenced by sugarcane farming area, the use of ZA fertilizer, wage rate non-family of the human labor of sugar cane farming, and ratoons frequency. While the allocation of a family labor of sugarcane farming was influenced by sugarcane farming area, the use of the family labor of non-sugarcane farming, the number of household member of sugar cane farmer and ratoons frequency. Labor allocation of non-sugarcane farming was influenced by total nonsugarcane labor, while family labor was influenced by non-sugarcane farming area and nonsugarcane production. 
Influential variables of sugarcane production decision were sugarcane farming area, the use of NPK fertilizer and total household spending. Non-sugarcane production was influenced by variables of sugarcane farming, non-sugarcane labor, and surplus of sugarcane farmers households. The sugarcane farming production facility consisted of ZA fertilizer which was influenced by farming cost and ZA fertilizer price, while the influencing variables of the use of NPK fertilizer were sugarcane farming area and the use of ZA fertilizer.

Non-cane farming income as an endogenous variable in the structural equation in the household decision making of sugarcane farmer was significantly influenced by nonsugarcane farming area. While welfare indicator was seen from household spending of sugarcane farmers. Variable of sugarcane households surplus, the number of family members and energy expenditure have a significant influence on food expenditure. Non-food expenditure was actually influenced by non-sugarcane farming income and total household income of sugarcane farmers.

Sugarcane farmers household decision-making cannot be separated from the ability of farmers to combine input usage, labor allocation, and household spending. Ratoons culture which becomes sugarcane development in the research area, if exceeding ratoons frequency recommended by the government, will cause the decrease of production and quality of sugarcane. So that in order to improve it, it was required the availability of capital, technology adoption and government policy on increasing the price of output and subsidy input and the synergic relationship between farmers and downstream industries.

\section{REFERENCES}

1. Angga Naruputro.(2009). Sugarcane Management in Krebet Baru Sugarcane, PT.Rajawali I Malang, East Java With Special Aspect Count Productivity in Every Plants Categories. Makalah Seminar.Agronomi Dan Hortikultura.Institut Pertanian Bogor.

2. Balai Penyuluhan Pertanian.Kecamatan Gondanglegi. (2015).

3. Becker GS.1965.a Theory of the allocation of time.Econ J.75(2009): 493-517.

4. Barnum H.N., and L. Squire. (1979). A Model of an Agricultural Houshold. Theory and Evidence, Published for the World Bank, The Johns Hopkins University Press. Baltimore and London.

5. Bagi, F.S. and Singh, I.J. (1974). A Microeconomic Model of Farm Decision in an LDC. A Simultaneous Equation Approach. Department of Agricultural Economic and Rural Sociology.The Ohio University. Ohio.

6. Chang, Yang-Ming, Biing-Wen Huang and Yun Ju Chen. (2011). Labour Supply, Income and Walfare of The Farm Household. Departement of Economics Paper Kansas State University.

7. Direktorat Jendral Perkebunan.(2015).Outlook Tebu.Pusat Data dan Sistem Informasi Pertanian Sekretariat Jendral Pertanian-Kementerian Pertanian.

8. Ellis F.(1988). Peasant Economics: Farm Hiusholds and Agrarian Develompment Analysis. Fifth Edition. Jhon Wiley and Sons Inc., New York.Ol: http: //dx.doi.org/10.21082/jae.v35n2.2017: 127-150.

9. Fadilla Ristya Aminda.Bonar Marulitua Sinaga.Anna Fariyanti. Dampak Faktor Eksternal Terhadap Kesejahteraan Rumah Tangga Petani Tebu Keprasan Di Jawa Tengah.Jurnal Agro Ekonomi Vol.35 No.2.Desember 2017: 127-150 D.

10. FAO. (2015). FAOSTAT Statistical Databases. Food and Agriculture Organization of the United Nations, Rome, Italy.

11. Fitriani.Sutarni and Luluk Irawati.(2013). Factor Affecting Production, Consumption and Work Expended Sugarcane Farmers in Lampung Province.ESAI IImiah Journal (7)1 January 2013: 1-11.

12. Hanani, N. and Yonekura. (2009). Economic Decision Making of Vegetable Peasant Household. http: //nuhfil.lecture.ub.ac.id /.../jepang-jurnal-nuhfil.pdf.

13. Kementerian Pertanian.(2016).Statistik Perkebunan Indonesia. Tebu 2014 - 2016. 
14. Kementerian Peilndustri. 2016.Revitalisasi Industri Gula. Kementerian Perindustrian Republik Indonesia.

15. Kumbhakar, C.S.(2002). Specification and Estimation of Production Risk, Preferences and Technical Efficiency. American Journal Agricultural Economic. 84(1), 8-22.

16. Koutsoyiannis.A.(1987). Theory of Econometrics. An Introductory Exposition of Econometric Methods. Second Edition. ELBS. Macmillan Education, Ltd., London.

17. Koswara, E. (1988). Pengaruh kedalaman kepras terhadap pertunasan tebu. Pros. Seminar Budidaya Tebu Lahan Kering. P3GI. Pasuruan. 332-334.

18. Leki S., N. Hanani, R. Dwiastuti, B. Setiawan.(2016) . Household Economic Decisions of Corn Farmers at West Timor, Indonesia. Current Agriculture Research Journal. 4 (1) June 2016: 74-83.

19. M.Dina Padilla-Fernandez and Petter lesie Nathall.(2011). Farm size and Its Effect on Productivity of Sugarcane Farms in Central Negros. The Pjilippines.J.ISSAAS.Vol.18. No.1: 49-61. 2012.

20. Makki, M. F. (2014). Perilaku Ekonomi Rumahtangga Petani Padi di Lahan Rawa Lebak Kabupaten Hulu Sungai Utara Kalimantan Selatan. PhD Thesis. Faculty of Agriculture, University of Brawijaya, Malang.

21. Ruxton, C.H., Gardner, E.J., McNulty, H.M., (2010). Is sugar consumption detrimental to health? A review of the evidence 1995-2006. Crit. Rev. Food Sci. Nutr. 50 (1), 1- 19.

22. Ratna Winandi Asmarantaka.(2007). Analisis Ekonomi Rumah Tangga Patani Tanaman Pangan Di Provinsi Lampung.Jurnal Agribisnis Dan Ekonomi Pertanian.(1)1: 1-18.

23. Rochaeni S, Lakolla EM. (2005). Faktor-Faktor Yang Mempengaruhi Keputusan Ekonomi Rumahtangga Petani di Kelurahan Satugede.Kota Bogor. Jurnal Agro Ekon 23(2): 133158.

24. Sekhampu TJ.Niyimbanira F.(2013). Analysis of the factors inflencing household expenditure in South African township.Int Bus Econ Res J.12(3): 279-284.doi 10.19030/iber.v12i3.7671.

25. T.M.Hess. J.Sumberg. T.Biggs. M.Georgescu. D.Haro-Monteagudo.G.Jewitt.M. Ozdogan. M.Marshall.P.Thenkabail.A.Daccache.F.Marin.J.W.Knox.(2016). A Sweet deal? Sugarcane, water and agricultural transformation in Sub Sahara Africa.Global Environmental Change 39 (2016): 181-194. 